Jelena Jovanović ${ }^{1}$

Biljana Grujić

Institute of Agricultural Economics, Belgrade
SCIENTIFIC REVIEW ARTICLE

doi:10.5937/ekonomika1601187J

Received: January 22, 2016

Accepted: February 16, 2015

\title{
HISTORICAL DEVELOPMENT OF CORPORATE GOVERNANCE AS THE BASIS FOR CURRENT CORPORATE TRENDS ${ }^{3}$
}

\begin{abstract}
The subject of this paper is to analyze different understandings of the term „,corporate governance“ which is, from the $14^{\text {th }}$ century to the present day, passing through various stages of development, definitions and procedures, stating the contributions of individual scientists. Then, it presents and analysis of corporate governance in the $21^{\text {st }}$ century (the importance of corporate governance is growing) and the trends that have already begun, expected to significantly alter this area in the forthcoming period (greater involment of shareholders in the company's operations, board's performance audit, the number of women in boards, the transparency of the company). The aim is to present different aspects of the management and functioning of the company's board, while increasing involvement of employees (shareholders) in corporate desicion-making. The purpose of this paper is to highlight the importance of corporate governance in modern business because with the increase in the number and scope of the organization there is also an increase of need for management.
\end{abstract}

Key words: corporate governance, company, board, modern business, code, trend.

JEL classification: B12, B20, B21, M12, M14

\section{ИСТОРИЈСКИ РАЗВОЈ КОРПОРАТИВНОГ УПРАВЉАҢА КАО ОСНОВА ЗА АКТУЕЛНЕ КОРПОРАТИВНЕ ТРЕНДОВЕ}

\begin{abstract}
Апстракт
Предмет рада је разматрање различитих схватања термина „корпоративно управљање “, који је од XIV века до данашњег дана пролазио кроз различите фазе развијања, дефинииија и процедура, уз навођење доприноса појединих научника. Потом, представљенаје анализа корпоративног управљањ у ХХІ веку (важност

\footnotetext{
1 jelena.jovanovic101@yahoo.com

${ }^{2}$ biljana_g@iep.bg.ac.rs

${ }^{3}$ Paper work is part of the project research 46006 ,, Sustainable agriculture and rural development in function of Republic of Serbia strategic goals achievement within the Danube region ", financed by the Ministry of Education, Science and Technological Development of the Republic of Serbia.
} 
корпоративног управљања расте) и трендови који су већ почели, а очекује се да ће значајно менати ову област у наредном периоду (већа укљученост акционара у пословање компаније, ревизија перформанси одбора, повећање броја жена у одборима, транспарентност компаније). Циљ рада је да се представе различити аспекти управљана и функционисања одбора компаније, уз повећање учешћа запослених (акиионара) у доношену компанијских одлука. Сврха рада је истииање значаја корпоративног управљања у савременом пословању јер са растом броја и обима организација, расте и потреба за управљањем.

Кључне речи: корпоративно управљање, компанија, управни одбор, савремено пословање, кодекс, тренд.

\section{Introduction}

Corporate governance as a way of thinking occurs centuries before the official use of this term. It can be said that it began to arise and develop as the companies in the simplest form of its existence. Starting from small entrepreneurs and their family business and all the way up to multinational corporations such as known today, the goal of establishment of each company was and remains to be the same - profit. With the Industrial revolutions, wars, changes and development of the world as a whole there have been changes, not only the conditions in which business is conducted, but also the size and the structure of the company.

The term corporate governance emerged in eighties of the $20^{\text {th }}$ century and its significance has increased the most at the beginning of the $21^{\text {st }}$ century. To a large extent it is influenced and shaped by codes of desirable behavior that are applied throughout the world, but bear in mind that not a small number of companies are adapting codes to their needs. Even when code is adjusted to a certain organization, in its core code consists of four cornerstones and they are: openness, integrity, honesty and responsibility towards shareholders, employees, the environment and all stakeholders. The successful implementation of the code and corporate governance in general significantly aggravate the increasingly complex forms of the company, both in structural and in geographical terms. What further complicates corporate governance in all countries of the world is changing business environment. Related to that, what also shoud be mentioned are numerous collapses which, in the world's leading companies, incurred as a result of insufficiently analyzed business options and potential (positive and negative) effects of such decisions taken. Confidence in corporate governance has often been shaken due to the poor selection of the primary objectives of management, therefore often in question were brought out their business ethics.

So far, the two biggest challenges of corporate governance were crashes of the companies from the beginning of $21^{\text {st }}$ century and in the same decade - the global financial crisis, which put in foreground disadvantages of corporate governance and the need for greater diversification in boards. All of above are only an indication that corporate governance over the years is getting more and more attention, and this trend continues in time to come. 


\section{Origin and development of corporate governance}

The idea of corporate governance is centuries old but the expression is new. The concept of governance is linked to the English writer Geoffrey Chaucer (c. 1343-1400). This concept in its history carries the stories of many ambitious people who have led companies into bankruptcy, and often did malfeasances that would increase their personal wealth (Tricker, 2012, pp. 4-5). There is an opinion that in some way corporate governance exists at least as much as there are forms of organization in which is possible to come to a conflict between those who invest their money and capital, and those who manage it.

Even in $18^{\text {th }}$ century Adam Smith in his book The Wealth of Nations (1776) observed a totally different interests between owners and company managers. From his point of view it seemed as insurmountable problem for the efficiency of the corporation. According to him ,directors, as managers of other people's money, can never take account of that money with the same caution as they would with their own money" (Wells, 2010, p. 1251).

The beginning of the $19^{\text {th }}$ century was marked by great economic growth caused by the Industrial revolution and during this period many companies needed external capital in order to keep up with this growth. Already in 1807 in France appeared type of company that makes it possible. In this type of company CEOs were still exposed to the company's debt, but external investors had limited liability. In this regard, the British Parliamend considered the need of raising capital without exposure of external investors to the risks in case of bankruptcy. Although some members of Parliament were for the system that was implementing in France, according to the Acts of 1855 and 1862 , all shareholders had limited liability - whether they were part of the company's management or not.

New changes have occured already by the beginning of the $20^{\text {th }}$ century. In the UK, US and many other developed countries companies have become large and complex - shareholders became numerous, geographically widespread and diverse in terms of expected returns. At that time an increasing number of companies had shares listed on stock exchange, the number of intermediaries was increasing and thus the investors and managers became more and more remote. As the years passed many questions have been arrisen, such as the requirement for companies to have audit committee as a permanent body which would be composed of independent external directors; or the role of state enterprise in society and their legal and moral obligations (Cadbury, 1992, p. 16).

The corporate social responsibility concept within which companies integrate concern for society and environment as a whole and accordingly direct interaction with shareholders and course of action for the company attracted a lot of attention in the 1970s. Numerous authors have recognized the impact that company activities have on the external environment and it was suggested that one role of accounting reports should be focused on this issue. But there were authors who believed that there is no reason why shareholders would tolerate non-profit activities of the company because it would reduce their dividends and company's earnings. On this topic Milton Friedman in 1970 said that „to the company there is only one social responsibility - to engage their funds in activities that are designed to increase profit, but without violating the rules of the game (Crowther, 2008, pp. 11-12).

The most importat milestone in the development was the one which referred to the first concrete shaping and defining this term - the formation of expression corporate governance 
that emerge in 1980s and quickly was accepted worldwide. Already in 1988 Philip L. Cochran and Steven Leslie Wartick published Bibliography of corporate governance, and only four years later was founded a research journal that specializes in this area. Same year (1992) in the UK was created Corporate governance Code $e^{4}$ in which first time was defined what is meant by good business practice. This Code was intended for all members of the board of directors all companies whose shares are listed on stock exchange, but also served as an incentive for other companies to align their operations with the Code. Basic principles of the Code were opennes that should exist between the company and everybody who have a stake in its success; integrity refers to the clear and complete business, that is, the financial statements should be honest and reflect a clear picture of the company's situation; and responsibility of the board of directors refers to their responsibility to the shareholders in terms of the quality of information they provide, but aso the responsibility of shareholders to perform their duties which they have as owners (Tricker, 2012, pp. 4-7). Code was changed and evolved over the years and its last edition was publishes in September 2014 (this will be discussed later).

\section{Corporate governance and $21^{\text {st }}$ century}

At very beginning of $21^{\text {st }}$ century corporate governance gets above all the attention, and reason for this lies in the growing number of scandals and crises that occured in those years. Collapse of companies such as Enron, WorldCom, Tyco and others led to numerous re-examination of the role of the committee, auditors, independent directors and so on; and that led to questioning the professional ethics of the companies.

The scandals and crises are in fact merely the manifestation of a number of structural problems for which corporate governance gained and keeps increasingly gaining in importance in field of countries economic development. The cause of the problem is in several segments, such as: privatization - which drew a number of issues of corporate governance in the areas that were previously in hands of the state; technological development, liberalization and the opening of financial markets, free trade and other structural reforms make the importance of corporate governance grows, and with time it becomes more complicated; the growning role of institutional investors through the mobilization of capital and increases the need for well-managed arrangements; growth of international financial integration, trade and investment create difficulties in corporate governace across their borders (Claessens, 2003, pp. 6-7).

Crash from the beginning of the $21^{\text {st }}$ century was followed by a new collapse that hit the whole world - it was crisis 2007/2008. As a result of the financial crisis obvious weaknesses due to which corporate governance fell test became apparent. The reason was the fact that management routines have not served the purpose - many companies engaged in finacial services did not protect themeselves from taking exessive risks. After all of this became apparent, the importance of qualified monitoring of board and common risk management as well as widely accepted standars (which are not limited only to fnancial institutions) and accordingly further develop the Code (Kirkpatrick, 2009, p. 3). Code changed over the years and last edition of UK Corporate governance

\footnotetext{
${ }^{4}$ For more information see: The Financial Aspects of Corporate Governance, The Committe on the Financial Aspects of Corporate Governance and Gee and Co. Ltd., 1992.
} 
Code was published in 2014 by the Financial Reporting Council (FRC, 2014, pp. 5-23) and it points out the following basic principles:

- Leadership - there should be a clear division of competences and responsibility between the supervisory and exectutive boards. Chairman is responsible for management board and for ensuring its success in all aspects;

- Effectiveness - the board and its committees should have appropriate range of characteristics, ie. skills, experience, independence and knowledge about company that allow effective performance of their duties;

- Accountabillity - the board should present a fair, balanced and understandable assessment of company's status and prospects. Board is responsible for determining the nature and extent of the main risks, and it should find a reasonable way to manage them. Also, board should establish transparent principles of corporate reporting, risk management and internal controls;

- Remuneration - compensation of executive directors should be designed in that way to encourage the long-term success of the company. There should be a formal and transparent procedure for developing policy on the compensation of executive management, as well as for fixed salaries of individual directors (no director should be involved in deciding on the amount of their own fees);

- Relations with shareholders - on the basis of a common understanding of goals there should be a dialogue with shareholders and in charge for that is board as a whole. Board should use regular meetings to communicate with investors and to encourage their participation.

Corporate governace Code propose that board shall consist of at least hald of independent non-executive directors and according to Grant Thornton's annual report corporate governance, on average, committees in the UK consists of 9.5 members and 5.7 of them are independent non-executive directors. In the US, the situation is slightly different so the average size of the board is 10.7 members and on average 9.1 of them are independent non-executive directors (Grant Thornton, 2014, p. 21). Graphically illustrated it looks like this:

Graph 1: Participation of non-executive directors on boards

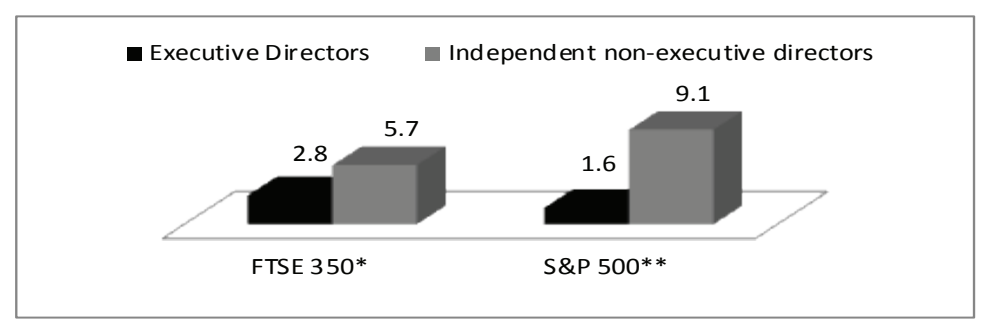

Source: Grant Thornton, 2014.

* The FTSE 350 is a market capitalisation weighted stock market index incorporating the largest 350 companies by capitalisation which have their primary listing on the

London Stock Exchange.

** The S\&P 500 is an American stock market index based on the market capitalizations of 500 large companies having common stock listed on the NYSE or NASDAQ. 


\section{Trends in the development of corporate governance in modern business}

Corporate governance over the years is getting more and more attention. It is expected that this will be the case in the time to come and that boards will be carefully monitored by investors, customers and all other stakeholders. In the text bellow is a list some of the trends and issues which are considered that will shape this area in the next period:

- more independent directors and advisers - directors and advisers may be formally independent, but still trapped inside the meeting hall;

- $\quad$ greater responsibility of shareholders - there is a tendency to put shareholders in more involved role in business decision-making process and accordingly board should hold executive meetings with long-term shareholders in order to discuss the risks, salaries, value of the company and management as a whole;

- focus on strategy and value creation - profit - the focus of any good board should be aimed at the creation of value and monitoring of the plan realization. This trend brings problems to an inexperienced boards and directors who have recieved hteir position through inheritance;

- board performance audit-regulation, activism, technical and public tributaries are leading to the objective standards for evaluation of activities conducted by directors (and lack of them). Failures in the existing management patterns (bribery, corrpution, poor performance) often took place in companies whose management system was taken as a good example. That is why now is going toward an independent, internal and deep revision of board, risks and control. Management can not guarantee for their good work and same situation is for boards - board can not revise its work.

- $\quad$ growing pressure from the public and the media about compensation - these pressures have resulted in relugations for the harmonization of fees, but the role of boards in the executive compensation process still requires much attention and also payment based on performance operating activities and gains arising in specific circumstances still remained unregulated (Lebland, 2014; Kumar, Zattoni, 2016, p. 1).

- perhaps one of the most obvious trends in corporate governance is focus on members, diversity and committees performance. Regulation is increasingly moving up to the prescribed competencies, biographies etc. in order to determine wheter all members of board actually correspond to the scope of their activities. Boards are increasingly under pressure to evolve to meet the expectations and successfully meet the challenges. So, directors are nowdays more than ever focused on board members and need that they have appropriate knowledge and experience to make their work more effective (PwC, 2014, p. 4).

The following graph shows the results of a survey conducted by $\mathrm{PwC}$ company that specializes in audit, insurance, consulting services and others. The result shows that the most important features of board members are knowledge in finance $(93 \%)$, industry in which company operates $(72 \%)$, operational functions $(68 \%)$, risk management $(65 \%)$. Less than half of respondents believe that is very important knowledge about international business 
(45\%), technology and digital media (41\%), sexual diversity (37\%) and marketing (33\%). Knowledge of racial diversity (28\%), human resources $(22 \%)$ and legal aspects $(21 \%)$ are considered to be the least important.

Graph 2: Desirable knowledge of board members

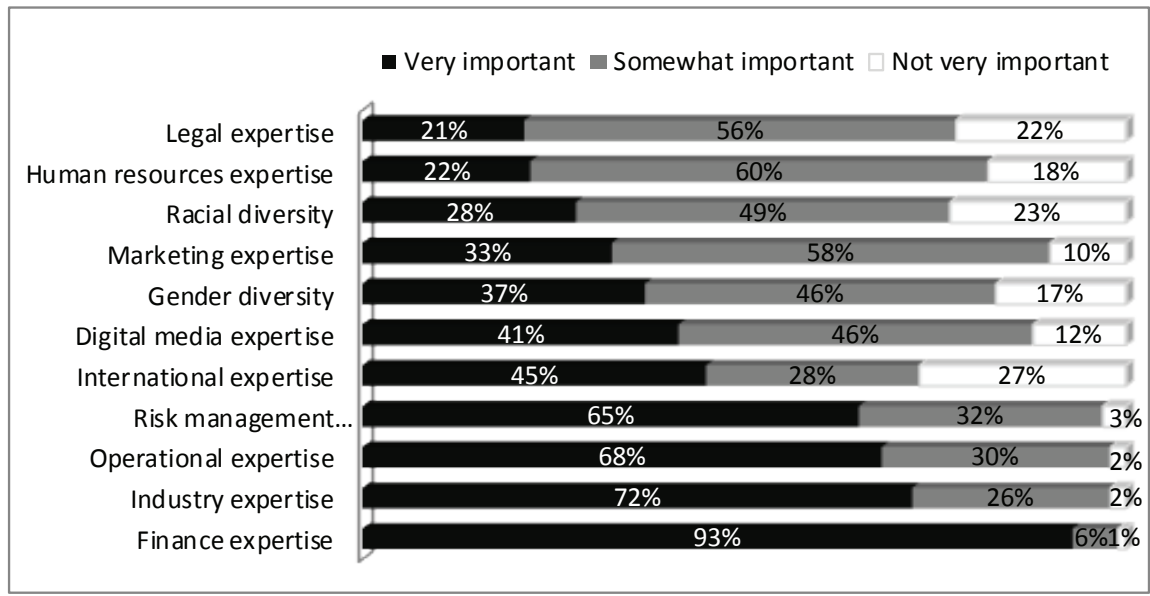

Source: PwC, 2014.

*due to rounding the sum of percantages in the chart can be less than 100

When it comes to women in boards in recent years that topis is pervasive. Although it was observed that the number of women on the boards is growing, the increase is still quite small. The company Thomson Reuters in October 2014 announced the results of an analysis they conducted. That study included 4,255 companies which can be found in ASSET4 ESG ${ }^{5}$ database (Chanavat \& Ramsden, 2014, pp. 1-2). As shown in Graph 3. compared to 2009 when $13 \%$ of companies reported to have $20 \%$ or more women on boards, in 2013 that percentage rose only up to $20 \%$.

\section{Graph 3: The percentage of women on boards}

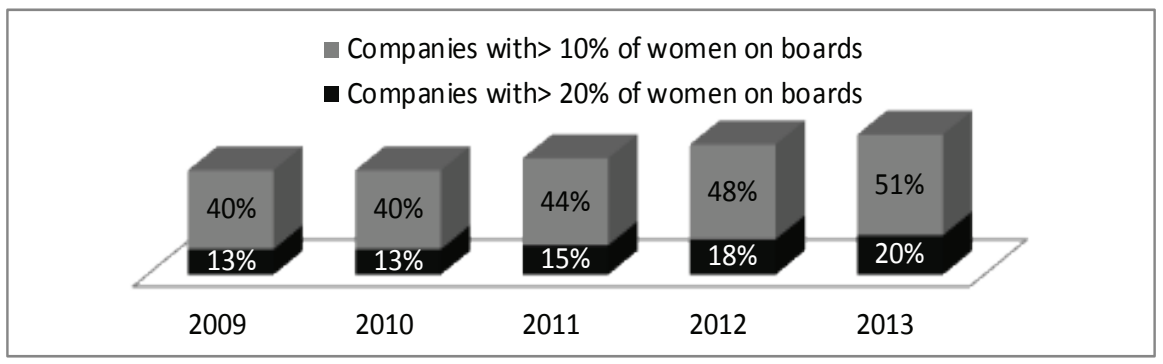

Source: Thomson Reuters, 2014.

\footnotetext{
${ }^{5}$ A database where you can see and evaluate the company based on 750 individual criterias which are connected to over 250 business performance indicators.
} 
It is expected that these percentages will be higher in years to come because many countries have adopted qoutas on how much women should be on boards. Thus, for example, in the Netherlands company over 250 employees should have at least $30 \%$ of women and 30\% of men on the boards; in France until 2017 companies whose shares are listed on stock exchange and have more than 500 employees should have $40 \%$ female representation on boards; in Japan two years ago was announced target quota of up to $30 \%$ of women in executive positions which is, due to the deep foundations of culture, a very high percentage for this country (Orsagh, 2014).

- transparency as key to success - providing greater insight into company politics and business moves will encourage shareholders to engage in the companies in which they invest, because the more shareholders know they will be more motivated to be involved in the life of the company. This is also true for applying the principles of corporate governance - shareholders should be familiar how to apply these principles, and in case where principles are not applied - reasons should be explained and members should together come to solutions to problems. And it is expected that in 2016 companies will be more oriented on rules on disclosure which would lead to increased transparency (European Confederation of Institutes of Internal Auditing, 2013, pp. 3-4; Goodman \& O'Kelley, 2016, p. 4).

- one of the areas of directing research in this field is connection between the ownership structure and performances, because in companies with complex ownership structure too little is known about the owners, the role of shareholders, relations between shareholders and their representatives in boards and how all of this affects the private, state-owned companies and institutional investors. Likewise, in the growning markets of developing countries it is necessary to investigate in detail the relationship between the corporation and all stakeholders (Claessens \& Yurtoglu, 2012, pp. 41-45).

- $\quad$ risk management as old, but problem with more challenges is one of the most difficult tasks for corporate governance today. In order to be competitive and to beat rivals companies have to manage a complex business, financial, legal and other risks that require constant monitoring, technical expertise and resources. The paradigm of risk management has evolved from the fact that it is primarily commercial and operational management responsibility, to the point that it comes within the scope of board responsibility. The fact is that companies that introduce completely new products and services, or new technologies achieve a significant advantage but they also bear a significant risks In recent years, a segment that is gaining attention is information technology management. The rapid progress of technology has created great opportunities, but also risks. The root of these risks lies in the ignorance of technology by many, if not most of the board memebers which prevents effective management and monitoring. Companies are increasingly relying on business over the internet and mobile devices which increases their vulnerability due to more frequent and sophisticated cyber attacks (Lipton \& others, 2014, pp. 2-11; Jovanović, 2015, p. 149) 


\section{Conclusion}

The concept of corporate governance is as old as the concept of company itself (even in the simplest sense of organization), so it can not be observed only from the eighties of the $20^{\text {th }}$ century and the time of occurrence of the term. With the increase of number and size of the organizations, the need for management did also increase. All types of organizations, ranging from small family all the way up to multinational corporations whose capital can be measured by capital of smaller country have always had same fundamental objective, which is to maximize profit. Very common problem that is related to this objective is gap between primary goal one who invest capital, and those who manage it. Through history, often this gap led to the bankruptcy of the company, and that led to shaken confidence in those who manage capital.

The problem of confidence in managers escalated with collapses that arose at the beginning of the $21^{\text {st }}$ century. In order to restore confidence in managers, companies over the years are more and more directed into involment of the independent non-executive directors on their boards; which were mostly composed of male members and in time that led to strengthening requirement that women should also be an equal members of the board. The shaken confidence in corporate governance emerged a trend tightened, independent and profound revision of companies board of directors, as well as an increasing public pressure for harmonization of fees regulations and greater transparency of company operations.

Board and investors should focus on the effect that company achieves, and over time it became increasingly evident that company activites do not affect only internal but also external environment. Although there was an opinion that earning profit for companies is not just essential but the only target, failures of companies have shown that subjects who were led by policy of this kind were wrong and that every business system must take into account what kind of impact it has on all stakeholders. One the one hand, companies should find a way to create a balance between earning profits; and on the other hand, the effects they have on the environment, employees and all others who are in some way influenced by it. Corporate governance should contribute to longterm sustainable development, because there is a feedback between every company and environment in which they exist - environment benefits from successful company, and company can have benefit from environment that support its development.

One of the problems with which corporate governance was faced throughout history, and no doubt will face in future, is a risk. In the past, risk management that was not good enough had put companies through painful shocks and now danger of that outcome increases every year. In addition to general risk, companies in modern business are facing a new challenge - information technologies. Companies are in increasingly relying on information technologies, so if they do not exploit its potential, educate employees and keep up with the latest trend they may face serious consequences.

World economic and legal environment is constantly changing and corporate governace should follow these changes through codes and principles of conduct, but that is not enough. Each company is an organism for themselves and in addition to general code every company should have its own rules and should adapt them to their and characteristics of environment in wich company conducts its business. Similary, every company should follow development and trends of industry in which it operates, but also in the areas of 
corporate governance so it could be in time introduced to demands, risks, aspirations and all possibilities that exist in the area of its business.

\section{References}

Cadbury A., (1992). The Financial Aspects of Corporate Governance, A Report of the Committe on Corporate Governance, Gee \& Co, London.

Claessens S. (2003). Corporate Governance and Development, A Global Corporate Governance Forum, Focus 1, The International Bank for Reconstruction and Development, Washington.

Claessens S. \& Yurtoglu B. (2012). Corporate Governance and Development - An Update, A Global Corporate Governance Forum Publication, Focus 10, International Finance Corporation, Washington.

Crowther D. \& Aras G. (2008). Corporate Socail Responsibility, BookBoon, ISBN 97887-7681-415-1.

Chanavat A. \& Ramsden K. (2014). Climb to the top - Tracking gender diversity on corporate boards, Thomson Reuters Financial and Risk, Thomson Reuters (http:/ thomsonreuters.com/en/articles/2014/tracking-gender-diversity-on-corporateboards.html, 22.12.2015).

European Confederation of Institutes of Internal Auditing (2013). The Future of Corporate Governance, Key Views from Key People (доступно на: http://www.eciia.eu/wpcontent/uploads/2013/10/ECIIA-Future-of-corp-gov-2-10-13.pdf, 17.01.2016).

Financial Reporting Council (2014). The UK Corporate Governance Code, London (https://www.frc.org.uk/Our-Work/Publications/Corporate-Governance/UKCorporate-Governance-Code-2014.pdf, 28.12.2015).

Fraser I. A. M. \& Henry W. M. (2003). The Future of Corporate Governance: Insights from the UK, The Institute of Ahartered Accountants of Scotland CA House, Edinburgh.

Goodman A. \& O’Kelley J. (2016). Global and Regional Trends in Corporate Governance for 2016, Russel Reynolds Assocites (http://www.russellreynolds. com/insights/thought-leadership/Documents/Global\%20and\%20Regional\%20 Trends\%20for\%20\%20Corporate\%20Governance\%20in\%202016.pdf, 21.01.2016.).

Grant Thornton (2013). Governance steps up a gear, Corporate Governance Review.

Grant Thornton (2014). Plotting a new course to improved governance, Corporate Governance Review.

Jovanović, Z. (2015): Management and changes in business environment, Journal Ekonomika, Vol. 61, No. 2, Society of Economists "Ekonomika”, Niš, pp. 143-151.

Kirkpatrick G. (2009). The Corporate Governance Lessons from the Financial Crisis, OECD, Pre-publication version for Vol. 2009/1.

Kumar P. \& Zattoni A. (2016). Executive Compensation, Board Functioning, and Corporate Governance, Corporate Governance: An International Review, John Wiley \& Sons Ltd, doi:10.1111/corg.12150, 24(1), pp. 2-4. 
Leblanc R. (2014). 2015 Trends and Answers in Corporate Governance, Huffington Post (http://www.huffingtonpost.ca/richard-leblanc/2015-trends-and-answersi_b_6296364.html, 28.12.2015).

Libert B. (2013). Governance 2.0: the future for boards in the age of big data, Corporate Secretary (http://www.corporatesecretary.com/articles/technology-socialmedia/12562/governance-20-future-boards-age-big-data/, 20.12.2015).

Lipton M, Rosenblum S. A. \& Cain K. L. (2014) Some Thoughts for Boards of Directors in 2015, Harvard Law School Forum on Corporate Governance and Financial Regulation (http://corpgov.law.harvard.edu/2014/12/02/some-thoughts-for-boardsof-directors-in-2015/, 08.01.2016).

Organization for Economic Co-Operation and Development (2004). OECD Principles of Corporate Governance.

Orsagh M. (2014). Women on Corporate Boards: Global Trends for Promoting Diversity, Cfa Institue (http://blogs.cfainstitute.org/marketintegrity/2014/09/24/women-oncorporate-boards-global-trends-for-promoting-diversity/, 25.12.2015).

PwC (2014). Governance trends shaping the board of the future, Board performance and diversity, Annual Corporate Directors Survey (http://www.pwc.com/us/en/corporategovernance/annual-corporate-directors-survey/assets/pdf/annual-corporatedirectors-survey-2014.pdf, 15.01.2016.).

Russell Reynolds Associates (

Sullivan J. D. \& Nadgrodkiewicz (2013). Looking Toward the Future: The Business Case for Corporate Governance, Center for International Private Enterprise (http:// www.cipe.org/publications/detail/looking-toward-future-business-case-corporategovernance, 20.12.2015).

Tricker B. (2012). Corporate Governance: Principles, Policies and Practices (Second edition), Oxford Unversity Press.

Wells H. (2010). The Birth of Corporate Governance, Law Review, Vol. 33, No. 4, Seattle University, pp. 1247-1292. 